\title{
Growth, relative chlorophyll content and concentration of inorganic solutes in sunflowers plants supplemented with marine macroalgae organic residue ${ }^{1}$
}

Paulo Ovídio Batista de Brito ${ }^{2}$,Kaio Martins ${ }^{3}$, Rifandreo Monteiro Barbosa ${ }^{3}$, Julyanne Fonteles de Arruda ${ }^{3}$, Pedro Bastos de Macedo Carneiro ${ }^{4}$, Franklin Aragão Gondim ${ }^{2 *}$

10.1590/0034-737X201865050003

\begin{abstract}
One effect of the tidal dynamics is the accumulation during of large volumes of macroalgae the low tide, named "arribadas algae". The objective of this work was to analyze the effects of using arribada alga eorganic residues (AAOR) on the initial growth of sunflower plants, where the following were evaluated: plant growth, relative chlorophyll content and inorganic solids content $\left(\mathrm{Na}, \mathrm{K}, \mathrm{Cl}\right.$ and $\mathrm{NO}_{3}$ ). The algae were collected on Praia do Pacheco in Caucaia, state of Ceará, Brazil, washed in running water and placed to dry in the sun for seven days, then dried in a forced circulation oven at $80^{\circ} \mathrm{C}$ and crushed. The sunflower seeds were sown in $5 \mathrm{~L}$ plastic buckets, containing: 1) $100 \%$ (in volume) of sand; 2) sand $+100 \%$ of nitrogen recommendation - NR in commercial fertilizer ( $\left.80 \mathrm{~kg} \mathrm{of} \mathrm{N.ha}^{-1}\right)$; 3 ) sand $+50 \%$ of the NR in macroalgae; 4 ) sand $+100 \%$ of NR in macroalgae; and 5) sand $+150 \%$ of the NR in macroalgae. The use of AAOR improved the growth of the analyzed variables in relation to the plants grown in substrate with sand or sand + fertilizer. The best results were observed at $50 \%$ of the NR in AAOR. The addition of increasing concentrations of AAOR allowed a greater accumulation of beneficial ions such as $\mathrm{K}_{\text {and }} \mathrm{NO}_{3}^{-}$while no significant differences were observed for toxic ions such as $\mathrm{Na}$ and $\mathrm{Cl}$ in relation to plants supplemented with fertilizer or sand. The use of AAOR in substrates can be an alternative to fertilizers in plant cultivation since it reduces production costs besides being a sustainable destination.
\end{abstract}

Keywords: arribadas algae; Helianthus annииs L; organic residue.

\section{RESUMO}

\section{Crescimento, teores relativos de clorofila e concentrações de solutos inorgânicos em girassóis suplementados com resíduo orgânico de macroalgas marinhas}

Um dos efeitos da dinâmica das marés é o acúmulo de grandes volumes de macroalgas durante a maré baixa, denominadas de "algas arribadas". O trabalho objetivou analisar os efeitos da utilização deresíduos orgânicos de algas arribadas (ROAA) sobre o crescimento inicial de plantas de girassol avaliando-se: o crescimento das plantas, os teores relativos de clorofila e teores de solutos inorgânicos $\left(\mathrm{Na}, \mathrm{K}, \mathrm{Cl} \mathrm{e} \mathrm{NO}_{3}^{-}\right)$. As algas foram coletadas na Praia do Pacheco em Caucaia-CE, Brasil, lavadas em água corrente e colocadas para secar a sol pleno durante sete dias, em seguida, secas em estufa de circulação forçada a $80^{\circ} \mathrm{C}$ e trituradas. As sementes de girassol foram semeadas em baldes de plástico com capacidade para cinco litros, contendo: 1) 100\% (em volume) de areia; 2) areia + 100\% da recomendação de nitrogênio $\mathrm{RN}$ em fertilizante comercial ( $\left.\left.80 \mathrm{~kg} \mathrm{de} \mathrm{N} \cdot \mathrm{ha}^{-1}\right) ; 3\right)$ areia $+50 \%$ da RN em macroalgas; 4 ) areia + $100 \%$ da RN em macroalgas; e 5) areia $+150 \%$ da RN em macroalgas. A utilização de ROAA ocasionou melhoria nas variáveis de crescimento analisadas em relação às plantas crescendo em substrato com areia ou areia + fertilizante. Os melhores resultados foram

Submitted on April $24^{\text {th }}, 2018$ and accepted on August $20^{\text {th }}, 2018$

${ }^{1}$ This work is part of a study carried out for the discipline End of Course Paper in Environmental and Sanitary Engineering at Instituto Federal de Educação Ciência e Tecnologia do Ceará, Campus Maracanaú.

${ }^{2}$ Instituto Federal de Educação, Ciência e Tecnologia do Ceará, Programa de Pós-graduação em Energias Renováveis, Campus Maracanaú, Ceará, Brazil. paulobatistaengenharia @ gmail.com; aragaofg@yahoo.com.br

${ }^{3}$ Instituto Federal de Educação, Ciência e Tecnologia do Ceará, Campus Maracanaú, Ceará, Brazil. paulobatistaengenharia@gmail.com; rifandreo@gmail.com; kaiomartin@gmail.com ${ }^{4}$ Universidade Federal do Piauí, Teresina, Piauí, Brazil. pedrocarneiro@ufpi.edu.br

*Corresponding author: aragaofg@yahoo.com.br 
observados a 50\% da RN em ROAA. A adição de concentrações crescentes de ROAA possibilitou maior acúmulo de íons benéficos como $\mathrm{K} \mathrm{e} \mathrm{NO}_{3}^{-}$enquanto que não foram observadas diferenças significativas para íons tóxicos como $\mathrm{Na}$ e $\mathrm{Cl}$ em relação às plantas suplementadas com fertilizante ou areia. A utilização de ROAA nos substratos pode ser uma alternativa aos fertilizantes no cultivo de plantas, reduzindo custos de produção, além de ser uma destinação sustentável.

Palavras-chave: algas arribadas; Helianthus annuus L; resíduo orgânico.

\section{INTRODUCTION}

The production of seedlings is an important stage of the productive system; however, it is highly dependent on inputs. The use of renewable materials as a source of nutrients, besides being an interesting solution for waste disposal, is also an alternative for reducing the high input costs required for agricultural production (Trazzi et al., 2013).

The use of waste is an environmental management practice foreseen in the Brazilian National Solid Waste Policy (PNRS), Law no. 12.305/2010. The environmental aspect is also added, since the use of organic residues also allows the reduction in the production costs.

Brazil is a country rich in marine macroalgae diversity. It has approximately 800 taxa of identified marine macroalgae. The use of this resource represents a great potential for farming (Machado et al., 2011).

One effect of tidal dynamics and the action of sea currents and winds is the accumulation of large volumes of algae in the scorching regions during low tide. These algae are referred to as "arribadas algae". The removal of those arribadas algae is common for a later disposal by urban cleaning companies (Nova et al., 2014). However, it is generally known that this removal does not occur in any sand strip of the coast of Ceará state, Brazil. Thus, due to the economic, ecological importance and richness of nutrients, the objective of this work is to analyze the use of local macroalgae species for the fertilization of sunflower plants.

In order to verify the viability of the use of arribadas algae harvested for the production of substrates for plants, sunflower (Helianthus annuus L.) was chosen as the plant material. The crop shows desirable characteristics from an agronomic point of view, such as a short life cycle, high productivity, quality and oil yield, thus being a constituent of grain and biodiesel production systems (Araújo et al., 2012).

Sunflower is widely used in human diet because it presents an excellent quality oil, high stability to oxidation and nutritional and functional characteristics of the human diet. Regarding animal feeding, it is used in the form of bran, as silage and in diets for birds with their achenes. It is an important source of proteins for animal diets, besides the integrated participation in the production of honey, since it presents attractive potential of the flower for the bees (Freire, 2016). Among the various forms of use, the generation of energy is highlighted, as it is used as a raw material in the production of biodiesel.

The hybrid cultivar BRS 323 presents productivity and precocity, which makes it suitable for the different productive systems of the major agricultural regions in Brazil. The oil content is between $40 \%$ and $44 \%$. It is recommended for the brazilian states: Alagoas, Bahia, Ceará, Goiás, Maranhão, Mato Grosso, Mato Grosso do Sul, Minas Gerais, Pará, Paraná, Pernambuco, Piauí, Rio Grande do Norte, Rio Grande do Sul, Rondônia, Santa Catarina, São Paulo, Sergipe and the Distrito Federal (Embrapa, 2014).

\section{MATERIAL AND METHODS}

This work was carried out in a greenhouse located at Instituto Federal de Educação Ciência e Tecnologia (IFCE), in Maracanaú campus, Ceará, Brazil, from June to August in 2017.

Algae were collected in Praia do Pacheco, Caucaia, Ceará, on April 15, 2017 from 13:00 h to 15:00 h at a 0.4-m tide, according to the tide table of Porto do Pecém-CE and waning gibbous moon. Samples of algae that were over the strip of sand completely uncovered by the sea during the low tide were manually collected. The samples were taken still fresh preserved at $4{ }^{\circ} \mathrm{C}$ in a thermal box and sent to the laboratory of Macroalgae located at the Instituto de Ciências do Mar - Labomar at the Universidade Federal do Ceará for identification.

Three species of red algae were found: Glacilaria ornata, Glacilaria cervicornis, Glacilaria cearensis, which represented the largest proportion of the sample (approximately 70\%). The following were detected in smaller proportions: Gelidiopsis gracilis, Botryocladia occidentalis, Caulerpa prolifera, Ulva faciata, Hypnea pseudomusciformise, Gelidium coarctatum.

After, masses of different species of algae were collected jointly to prepare the substrates for the cultivation of sunflower plants. Following removal, the algae were washed in running water and arranged to be 
dried in the sun for about 7 days. Subsequently, the material was sent to Laboratório de Bioquímica e Fisiologia Vegetal (Laboratory of Biochemistry and Plant Physiology) at IFCE, Maracanaú campus for completion of the drying process in an oven with forced air circulation at $80{ }^{\circ} \mathrm{C}$ until reaching constant mass. After total drying, the material was crushed using mortar and pistil and called arribadasalgae organic residues (AAOR). Followingthis procedure, a sample of the material was sent for analysis in Laboratório de Solos/Água (Soil/Water Laboratory) at the Universidade Federal do Ceará (Table 1), where the total nitrogen concentration (N) was determined at 39.8 g. $\mathrm{kg}^{-1}$ used in calculations for the AAOR amounts added to the substrates. For the mixed organic fertilizer treatment, data of the analyzes which were carried out were provided by the manufacturer. The fertilizer was a mixture of cattle manure, sugarcane bagasse, wood sawdust, chicken manure and agricultural gypsum.

The sunflower seeds (cultivar BRS 323 granted by Embrapa Produtos e Mercados) were sown in $5 \mathrm{~L}$ plastic buckets. The experiment was set up in a completely randomized design, with five treatments: 1) $100 \%$ (in volume) of sand; 2) Sand $+100 \%$ nitrogen recommendation (NR) in mixed commercial organic fertilizer (following recommendation of the $80 \mathrm{~kg}$ of N.ha- ${ }^{-1}$ ); 3) Sand $+50 \%$ of NR in macroalgae; 4) Sand $+100 \%$ of NR in macroalgae; and 5) Sand $+150 \%$ of NR in macroalgae.

The sand used in all treatments was obtained in the river, with an average grain size (grains between 0.50 and $0.250 \mathrm{~mm}$ ), and prior to the utilization for the preparation of substrates, washing with distilled water was performed to leach the likely presence of salts. Each treatment consisted of 12 replicates, each consisting of a pot with two plants. The treatments were irrigated at $80 \%$ field capacity. Data of each collection were submitted to analysis of variance (ANOVA) and the means compared by the test of Tukey ( $p$ $<0.05$ ) using Sigma Plot 11.0 software.

Two measurements of the relative contents of chlorophyll and number of leaves at 15 and 22 days after sowing (DAS) and twoevaluations for height, stem diameters, leaf area and dry mass at 24 and 27 DAS were performed. The dry mass was determined after oven drying at $60{ }^{\circ} \mathrm{C}$ until reaching constant mass. The shoot constituted by leaves + petioles + stems and the roots and total (shoot + root) were measured as well.

For determination of concentrations of inorganic solutes, dried leaf extracts obtained from the maceration in mortar of $1 \mathrm{~g}$ of dry mass to $4.0 \mathrm{~mL}$ of deionized water were prepared. The macerate was then filtered on fine mesh nylon fabric and centrifuged at $12,000 \mathrm{x}$ for $15 \mathrm{~min}$. The supernatant was used as extract in the analyzes.

Chlorophyll relative contents were measured on the first fully expanded leaf counted from the apex using the Chlorophyll Meter SPAD-502 gear and data expressed as arbitrary units of the equipment (SPAD Index). The stem diameters were measured using a pachymeter, the number of leaves were manually counted, and the height of the aerial part was measured using a ruler, from the base of the stem to the insertion of the last fully expanded leaf.

\section{RESULTS AND DISCUSSION}

At 15 and 22 days after sowing (DAS), chlorophyll relative contents (Figure 1A) presented the greatest values for the plants in the treatment supplemented with organic algae residue (AAOR) at $150 \%$ of the nitrogen recommendation (NR). Next, the treatments at 100 and 50\% of the NR in AAOR stood out, not statistically differing from each other. The lowest values were observed in the commercial fertilizer treatment and sand. At 15 DAS, the $150 \%$ NR in AAOR was $18 \%$ greater than the groups at 50 and $100 \%$ of the NR in AAOR, and $80 \%$ greater than the commercial fertilizer and sand. At 22 DAS, the $150 \%$ of the NR in AAOR group was $23 \%$ greater than the groups of 50 and 100 of the NR in AAOR and $69 \%$ greater than the commercial fertilizer and sand groups.

For the height (Figure 1B) at 24 DAS, the $50 \%$ NR in AAOR treatment displayed an average value of $22.8 \mathrm{~cm}$ per plant, while the groups of 100 and $150 \%$ of the NR in AAOR showed average values of 18.5 and $15.8 \mathrm{~cm}$ respectively. Thus, the $50 \%$ of the NR in AAOR treatment presented values $23 \%$ greater than the treatment of $100 \%$ of the NR in AAOR and $44 \%$ greater than that of $150 \%$ of the NR in AAOR. The lowest results were found in the commercial fertilizer and sand groups, 11.5 and $13 \mathrm{~cm}$ respectively, not statistically different from each other. At 27 DAS, treatment of $50 \%$ of the NR in AAOR reached an

Table 1: Chemical analysis of the arribada algae organic residue (AAOR) and the mixed organic fertilizer used in the substrate composition for sunflower plant cultivation

\begin{tabular}{|c|c|c|c|c|c|c|c|c|c|}
\hline \multirow{3}{*}{ Treatments } & \multicolumn{9}{|c|}{ Chemical characterization } \\
\hline & \multicolumn{5}{|c|}{ g. $\mathbf{k g}^{-1}$} & \multicolumn{4}{|c|}{ mg. kg $^{-1}$} \\
\hline & $\mathbf{N}$ total & $\mathbf{P}$ & $\mathbf{K}$ & $\mathbf{C a}$ & Mg & $\mathrm{Fe}$ & $\mathrm{Cu}$ & $\mathbf{Z n}$ & Mn \\
\hline AAOR & 39.8 & 1.29 & 13.8 & 18.86 & 7.71 & $1,022.8$ & 8.1 & 41.1 & 652.8 \\
\hline Commercial Fertilizer & 2.2 & 8.43 & 8.10 & 1.52 & 1.85 & $3,445.5$ & 1.80 & 89.3 & 380.1 \\
\hline
\end{tabular}


average height of $26.7 \mathrm{~cm}, 16 \%$ greater than treatments 100 and $150 \%$, which reached averages of 24.8 and $21.3 \mathrm{~cm}$, and did not differed statistically from each other, and $90 \%$ greater than the commercial fertilizer and sand treatments, which reached averages of 13.8 and $14.2 \mathrm{~cm}$.

The number of leaves (Figure 1C) followed the same pattern for the two collections, where the three AAOR supplemented groups did not differ from each other and presented greater results than the commercial fertilizer and sand groups, which did not differ from each otherneither. At 15 DAS, the AAOR supplemented treatments presented six leaves per plant, on average, $35 \%$ greater than the others, which presented 4.3 leaves per plant, on average. At 22 DAS, AAOR supplemented treatments reached an average of 7.5 leaves per plant, being $36 \%$ greater than the others, which presented an average of 5.4 leaves per plant.

In relation to stem diameter (Figure 1D), at 24 DAS, the AAOR supplemented treatments did not differ among themselves and presented an average of $4.2 \mathrm{~cm}$ per plant, resulting in values $70 \%$ greater than the commercial fertilizer and sand treatments, which did not differ between themselves and presented an average of $2.4 \mathrm{~cm}$ per plant.
At 27 DAS, the 50 and 100\% NR groups, which did not statistically differ among each other and presented an average of $5 \mathrm{~cm}$ per plant, $25 \%$ greater than the treatment at $150 \%$ of the NR, which presented an average of $4 \mathrm{~cm}$ per plant. The treatment at $50 \%$ of NR was even $95 \%$ greater than commercial fertilizer and sand, which presented an average of $2.6 \mathrm{~cm}$ per plant.

Overall, the arribadas algae organic compound (AAOR) presents higher nutrient concentrations than the commercial fertilizer used in the experiment (Table 1). It is believed that this greater nutritional availability may have contributed to the increase of the biometric variables observed in Figure 1, where all AAOR supplemented groups presented greater results than the sand and commercial fertilizer groups. In addition, it is possible that AAOR presents greater availability of nutrients when compared to the mixed organic fertilizer, since it is crushed and easily absorbed.

It was observed that the accumulation of chlorophyll relative contents (Figure 1A) was proportional to the increase in AAOR concentrations.It is believed that this behavior is due to the greater concentration of $\mathrm{Mg}$ found

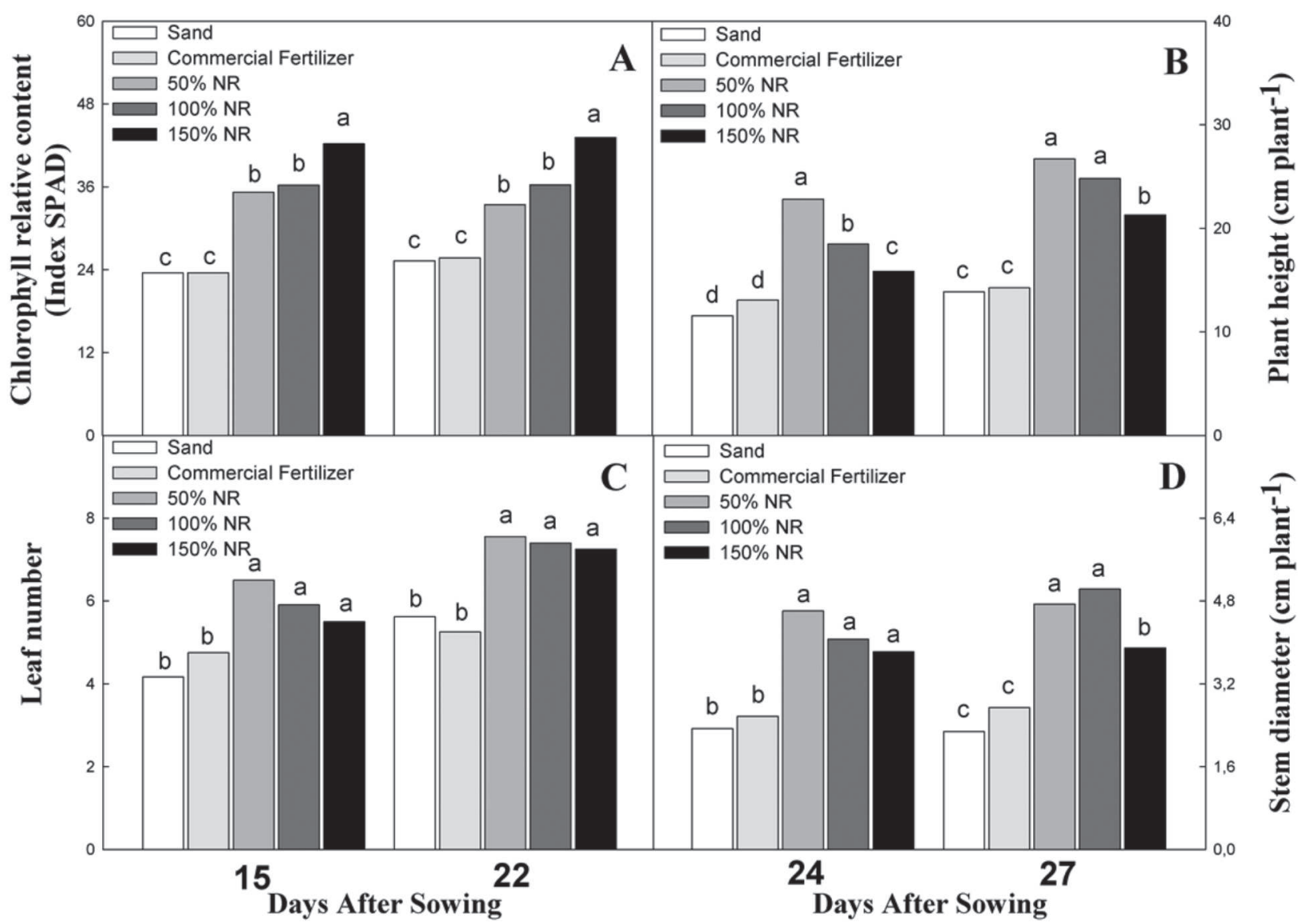

Figure 1: Chlorophyll relative contents (A), plant height (B), leaf number (C) and stem diameter (D) of sunflower plants in substrates containing: sand, commercial fertilizer or Arribada Algae Organic Residue at 50, 100 and 150\% nitrogen recommendation -NR. Bars followed by different letters are the statistical differences among treatments in each evaluation period according to the test of Tukey $(p<0.05)$.

Rev. Ceres, Viçosa, v. 65, n.5, p. 395-401, set/out, 2018 
in the organic compound in comparison to the commercial fertilizer (Table 1) because $\mathrm{Mg}$ is a forming element of the chlorophyll molecule, being essential for photosynthesis (Grangeiro et al., 2011).

Regarding height (Figure 1B) and diameter (Figure 1D), the greatest results were found for the 50 and $100 \%$ NR in AAOR group, while, although it had received larger amounts of nutrients, the $150 \%$ NR in AAOR group presented slightly lower values. It is believed that this has occurred because of the high concentration of Fe present in AAOR. Although Fe is an essential micronutrient for the normal growth and development of plants, its excess may cause nutritional dysfunctions and affect plant physiology (Adamski et al., 2011). Despite being a key micronutrient for the development of plant species, in some situations, Fe is able of being absorbed and accumulated in toxic concentrations (Sahrawat, 2005). Laurett et al. (2017) observed that Fe concentrations in nutrient solution over $45 \mu \mathrm{mol} . \mathrm{L}^{-1}$ reduced the development of lettuce Vitoria de Santo Antão and Rococó rucola. Thus, its greater concentration in the $150 \%$ NR in AAOR group may have limited the development in height (Figure 1B) and diameter (Figure 1D) when compared to the $50 \%$ and $100 \%$ NR in AAOR groups.
At 24 DAS, AAOR supplemented treatments presented average values of $1 \mathrm{~g}$ plant ${ }^{-1}$ of shoot dry mass (Figure 2A), a values that is $134 \%$ greater than sand and commercial fertilizer treatment, which presented average values of 0.43 g plant $^{-1}$. At 27 DAS, treatments at 50 and $100 \%$ of the NR did not differ between each other and presented 3 g plant $^{-}$ 1 , on average, $68 \%$ higher than the treatment at $150 \%$ and $472 \%$ in relation to the commercial fertilizer and sand treatments, which presented average values of 0.4 and 0.7 $\mathrm{g}_{\text {plant }}{ }^{-1}$, respectively.

For root dry mass (Figure 2B), the greatest values were observed in the treatments containing AAOR that did not differ among each other. At 27 DAS, the average of these values was $0.65 \mathrm{~g} \mathrm{plant}^{-1}$. The superiority was $675 \%$ in relation to commercial fertilizer and sand treatments, which presented an average of $0.08 \mathrm{~g} \mathrm{plant}^{-1}$.

Total dry mass (Figure 2C) presented a behavior similar to that of the aerial part dry mass. It stood out at $27 \mathrm{DAS}$, the values for the 50\% NR in AAOR that were 16, 100, 419 and $867 \%$ greater than the values for $100,150 \%$ of the NR and commercial fertilizer and sand treatments, respectively.

Other authors observed similar results. Rayorath et al. (2008), in a study with Arabidopsis thaliana, verified dry mass of the highest aerial parts in plant species under the

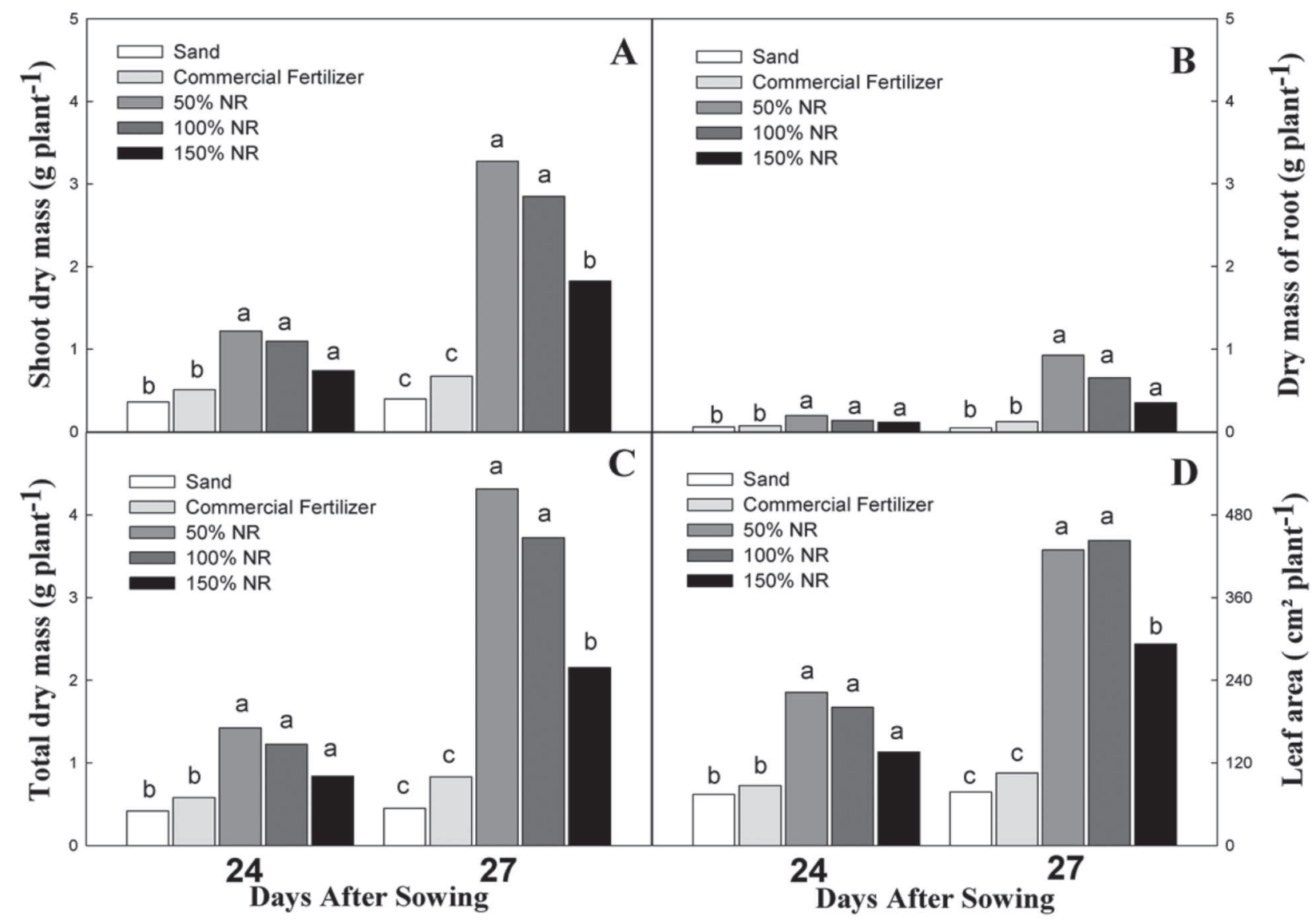

Figure 2: Shoot dry mass (A), dry mass of root (B), total dry mass (C) leaf area (D) of sunflower plants in substrates containing: sand, commercial fertilizer or Arribada Algae Organic Residue at 50,100 and 150\% nitrogen recommendation -NR. Bars followed by different letters are the statistical differences among treatments in each evaluation period according to the test of Tukey $(p \mathrm{~d}<0.05)$. 


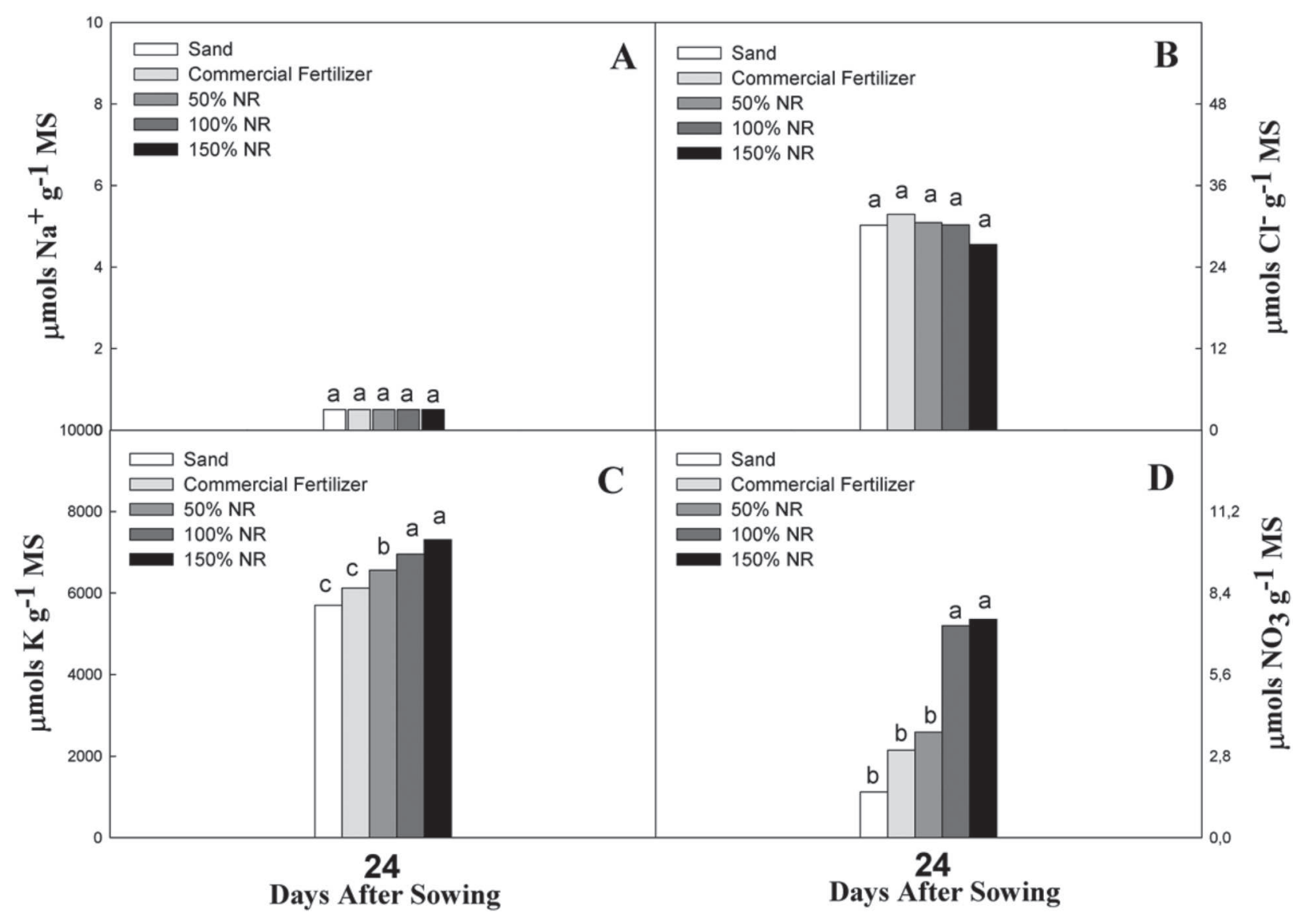

Figure 3: Sodium content (A), chloride (B), potassium (C) and nitrate (D) in sunflower leaves of plants in substrates containing: sand, commercial fertilizer or Arribada Algae Organic Residue at 50,100 and 150\% nitrogen recommendation -NR. Bars followed by different letters are the statistical differences among treatments in each evaluation period according to the test of Tukey $(p \leq 0.05)$.

effects of marine algae compounds as well as Kumar \& Sahoo (2011) in wheat plants and Matysiak et al. (2011) in maize.

Regarding leaf area (Figure 2D), the behavior was similarto that observed for dry mass. At 27 DAS, 50 and $100 \%$ of NR in AAOR treatments did not differ from each other and were superior to $150 \%$ of NR, commercial fertilizer and sand treatments by 49,315 and $462 \%$.

By the methodology used, the analysis of the Nacontents did not find significant concentrations in any of the groups evaluated (Figure $3 \mathrm{~A}$ ). In relation to $\mathrm{Cl}$ (Figure $3 \mathrm{~B}$ ), no significant differences were found in the treatments used in the experiment.

In relation to $\mathrm{K}$ (Figure 3C), the 100 and $150 \%$ treatments stood out, not differing from each other, being $8 \%$ greater than the $50 \%$ NR and $20 \%$ higher than the commercial fertilizer and sand treatment.

This result is considered positive, taking into account that $\mathrm{K}$ is an element that acts directly in plant nutrition, and performs several functions in the plant, such as: control of cellular turgidity, activation of enzymes involved in the respiration process and photosynthesis, regulation of the opening and closing of stomata, and transport of carbohydrate (Kano et al., 2010).
Yet, for nitrate $\left(\mathrm{NO}_{3}^{-}\right)$(Figure 3D), 100 and $150 \%$ NR in AAOR treatments were not statistically different among each other and were $172 \%$ greater than the average of the other treatments. This fact demonstrates a direct correspondence between the AAOR supplementation and leaf concentrations of $\mathrm{NO}_{3}^{-}$.

This relationship may be regarded as a positive factor, considering that $\mathrm{NO}_{3}^{-}$is an ion that benefits plant species. The $\mathrm{NO}_{3}^{-}$is related to metabolic regulation, absorption and assimilation of $\mathrm{N}$, which is essential in the production of proteins and nucleic acids, and to the mechanisms of regulation of nitrogen metabolism in the plant (Bredemeier \& Mundstock, 2000).

\section{CONCLUSION}

The use of arribadas algae organic residue (AAOR) resulted in an enhancement in the growth variables in relation to the plants growing in substrate with sand or sand + mixed organic fertilizer.

The use of AAOR in substrates can be an alternative to fertilizers in plant cultivation since it reduces production costs besides being a sustainable destination. 


\section{REFERENCES}

Adamski JM, Peters JA, Danieloski R \& Bacarin MA (2011) Excess iron-induced changes in the photosynthetic characteristics of sweet potato. Journal of Plant Physiology, 168:2056-2062.

Araújo TVO, Lima AD, Marinho AB, de Lima Duarte JM, de Azevedo BM \& Costa SC (2012) Lâminas de irrigação e coberturas do solo na cultura do girassol, sob condições semiáridas. Irriga, 17:126-136.

Bredemeier C \& Mundstock CM (2000) Regulação da absorção e assimilação do nitrogênio nas plantas. Ciência Rural, 30:365372

Embrapa - Empresa Brasileira de Pesquisa Agropecuária (2014) Cultivar de girassol BRS 323. Disponível em: https:// www.embrapa.br/busca-de-imagens/-/midia/1295001/cultivar-degirassol-brs-323. Acessado em: 10 de março de 2018.

Freire JO (2016) Cultivo do girassol irrigado sob diferentes lâminas de água e doses de nitrogênio. Tese de Doutorado. Universidade Federal Rural do Semi-Árido, Mossoró. 41p.

Grangeiro LC, De Freitas FC, Negreiros MZD, de TP Marrocos S, De Lucena RR \& Oliveira RAD (2011) Crescimento e acúmulo de nutrientes em coentro e rúcula. Revista Brasileira de Ciências Agrárias, 6:11-16.

Kano C, Cardoso AII \& Villas Boas RL (2010) Influência de doses de potássio nos teores de macronutrientes em plantas e sementes de alface. Horticultura Brasileira, 28:287-291.

Kumar G \& Sahoo D (2011) Effect of seaweed liquid extract on growth and yield of Triticuma aestivum var. Pusa Gold. Journal of Applied Phycology, 23:251-255.

Laurett L, Fernandes AA, Schmildt ER, Almeida CP \& Pinto MLPB (2017) Desempenho da alface e da rúcula em diferentes concentrações de ferro na solução nutritiva. Revista de Ciências Agrárias/Amazonian Journal of Agricultural and Environmental Sciences, 60:45-52.

Machado LP, da Silva Bispo WM, Matsumoto ST, Reis FO, dos Santos RB \& de Oliveira Jr LFG (2011) Triagem de macroalgas com potencial antifúngico no controle in vitro da antracnose do mamoeiro (Carica papaya L.). Current Agricultural Science and Technology, 17:463-467

Matysiak K, Kaczmarek S \& Krawczyk R (2011) Influence of seaweed extracts and mixture of humic and fluvic acids on germination and growth of Zea mays L. Acta Scientiarum Polonorum. Agricultura, 10:33-45.

Nova LLMV, da Silva Costa MM, da Costa JG, da Silva Amorim EC \& Guedes ÉAC (2014) Utilização de "Algas Arribadas" como alternativa para adubação orgânica em cultivo de moringa (Moringa oleifera Lam.). Revista Ouricuri, 4:68-81.

Rayorath P, Jithesh MN, Farid A, Khan W, Palanisamy R, Hankins SD, Critchley AT \& Prithiviraj B (2008) Rapid bioassays to evaluate the plant growth promoting activity of Ascophyllum nodosum (L.) Le Jol. using a model plant, Arabidopsis thaliana (L.) Heynh. Journal of Applied Phycology, 20:423-429.

Sahrawat KL (2005) Iron toxicity in wetland rice and the role of other nutrients. Journal of Plant Nutrition, 27:1471-1504.

Trazzi PA, Caldeira MVW, Passos RR \& de Oliveira Gonçalves E (2013) Substratos de origem orgânica para produção de mudas de teca (Tectona grandis Linn. F.). Ciência Florestal, 23:401409 . 